\title{
THE IMPACT OF CREDIT REPAYMENT SCHEDULE POLICY ON COMPETITIVENESS OF GRAIN PRODUCTION IN WELMERA DISTRICT, ETHIOPIA ${ }^{12}$
}

\author{
Mesfin Haile ${ }^{3}$
}

\begin{abstract}
In the last few years, agricultural polices were designed to benefit farmers. The agricultural extension program being implemented enabled smallholder farmers to use new agricultural technologies on time and hence increased productivity and output obtained per unit of land. However, credit repayment schedule policy put in place, forced farmers to repay input loans when price of output is very much low. The policy analysis matrix (PAM) was used for this study as a main methodology combined with a seasonal price Index. The study showed Welmera district having a comparative advantage for barley but not competitive while it has only a competitive advantage for tef and wheat. For two reasons farmers did not receive the actual price of grains that was equivalent with the true price. First, the system confirmed the presence of market failure in fertilizer market. Second, domestic cost of seed production was lower than the world price. The data also clearly pointed out how government policy negatively affected private profitability by undervaluing land. The seasonal analysis demonstrated price variability of grains exists in the study area. Moreover, the repayment period for input loan arranged when output prices are at their lowest levels. Therefore, the removal of credit repayment schedule policy would make grain production more competitive if farmers shift the sale of its produce to peak price periods. This call for review of the existing agricultural polices for the benefit of small scale farmers.
\end{abstract}

\footnotetext{
${ }^{1}$ The final version of this article was submitted in March 2007.

2 This paper was presented at the $11^{\text {th }}$ Annual Conference of African Econometrics Society, July $5^{\text {th }}$ $7^{\text {th }}, 2006$, Dakar, Senegal

${ }^{3}$ This paper is part of Mesfin Haile's dissertation for M.A. degree in the field of Economic Policy Management of Makerere University
} 


\section{Introduction}

Ethiopian agriculture in general and grain production in particular have gone through different policy regimes. Government usually used to design and implement several policies on national level. In some parts of the country the policy may bring intended benefit while in other parts of the country it becomes unsuccessful. Policy makers are therefore should be aware of the magnitude of policy effects on a separate region, zone or districts of a country. Presenting impact of a policy on different parts of the country serves as a base to prescribe alternative policy that contributes positively to the development of agricultural sector.

According to Pearson et al. (2003) policies influencing the agricultural sector fall into one of three categories - agricultural price policies, macro-economic policies, or public investment policies. Following the change of government in May 1991 Ethiopia has implemented Structural Adjustment Policy (SAPs) reforms. Ownership of private property legally recognized, however, ownership of land maintained as a property of the government. The local currency, Birr, was devalued from 2.07 to $5.00 \mathrm{Birr} / \mathrm{US} \$$ on October 1992 and this made domestic fertilizer prices higher compared to the previous years. According to Legesse et al. (2004), this called for the formulation of the national fertilizer policy in 1994. National Fertilizer Industry Agency (NFIA) was established to guide and regulate the fertilizer input sub sector. In 1994, in one hand, government approved and implemented direct fertilizer subsidy policy in a bid to avoid discouragement of fertilizer use by smallholder farmers. In 1997, a counteracting policy eliminated the direct fertilizer subsidy and the pan territory pricing. On the other hand, in 1994 from the lesson of SG 2000 project, the Ethiopian government launched a new extension system called Participatory Demonstration and Training Extension System (PADETES). The extension system comprises improved agricultural technologies given on credit basis. For most farmers in Ethiopia lack of credit is the cause why they didn't adopt agricultural technologies (Howard et al. 1995). According to CIMMYT (1993), credit may be an important factor in determining adoption of agricultural technologies. In PADETES, the credit is arranged as a package that provides a set of inputs to farmers.

Nonetheless, this credit scheme still needs some improvement for the benefit of the majority farmers. Credit system of the new extension program is more complex having multiple actors. Banks provide credit, regional governments guarantee credit and extension agents approve participants and collect payments (Arega and Rashid, 2003). The credit lacks realistic assessment of the borrowers' needs and the force used to ensure repayment of input loans right after harvest, discouraged many farmers from participating in the extension (Belay 2003; Croppenstedt et al. 2003). As 
a result, farmers were forced to sell their produce when the prices of agricultural produces are extremely low. The credit policy thus created an implicit price policy to grain production because right after harvest it causes the domestic grain prices to be lower than in the absence of policy. The lower output prices are also a disincentive to the use of agricultural technologies. These show the gap that this research tried to fill. This study was conducted in Welmera district in Ethiopia given it is dominated by peasant agriculture and hosted extension program since its inception. In the district barley usually used for consumption purpose while Tef and wheat partly serving as a cash crop. The objective of the study is to investigate the impact of credit repayment schedule policy on competitiveness of grain production.

\section{Research methodology}

\subsection{Methodology}

Policy Analysis Matrix (PAM) approach used to evaluate and measure the impact of credit repayment schedule policy on competitiveness of grain production. The methodology is based on the formulation of budgets for representative farm production activities (Monke et al., 1989; Pearson et al., 2003). PAM used by different researchers to evaluate and measure the effect of government policies on crop production. For example, Wiendiyati et al. (2002) studied the impact of tariff policy and inter-land transport costs on profitability of soybeans production in Ngoda Regency, NTT. Dipokusumo et al. (2003) evaluated impact of agricultural policy on soybean production in west Nusa Tenggara province, Indonesia. PAM used in Zimbabwe to evaluate the effect of removal of the special credit facility for the production of flue cured tobacco requirements (Winter-Nelson, 1991). PAM also used in Kenya to assesses dairy production and marketing in Nyeri. Since the PAM analysis requires the historical data on seasonal price variability, the 12 month moving average technique was used to examine seasonal output price variability. The moving average isolates the seasonal pattern by removing the influence of cyclical price movements and long-term trends. Seasonal price patterns are usually described by means of an index. This method is used by many researchers (Flaskerud et al. 2000; Ellis et al., 1997; Tschirley, 1995). The result of the seasonal price variability will be an input for the sensitive approach in order to determine the favorable repayment period of credit.

\subsection{Data type}

Cross sectional input-output data was used for both financial and economic analysis. These input-output data were collected in a case study conducted in 2003/2004 
production year from 48 smallholder farmers. Better off and resource poor farmers, as well as extension participant and non-participant farmers considered during the selection process. The case study include; among others, land holding and area under crop measured by compass traversing. Sides of each crop field measured with the help of measuring tape and compass bearings taken at each angle. Finally programmable calculator used to compute the area. Seeds and fertilizer measured with the weighting balance before it was applied to the field, stop watch used to measure duration of farm activities, outputs obtained weighted after trashing, and etc. The output price data for the period 1988 through 2004 was used to examine seasonal price variability. The 2003/4 production year credit repayment structure for extension participant examined to show when majority of matured credit are repaid for the borrowed loan of improved seeds, fertilizers and herbicides.

\section{Presentation of results}

\subsection{The policy analysis matrix}

\subsubsection{Macroeconomic assumptions}

Macroeconomic variables which affect the economic system include nominal interest rate, inflation rate, and official exchange rate. The information obtained from national bank indicated that nominal interest rate of loans was 10.5 percent per year, and the inflation rate was 9 percent per annum in 2003/4. Hence, the real interest rate per annum adjusted to inflation was estimated to be 1.5 percent. The average official exchange rate in the same year was observed to be 8.67 per US $\$$.

\subsubsection{Input and output coefficients}

Input-output data records were made in 2003/4. Inputs are divided into two, tradable inputs and domestic factors. Tradable inputs were those traded on international markets. The most important tradable inputs in the study area were seeds, fertilizers (DAP, and Urea), and herbicide. The most commonly growing improved barley varieties in the study area were Baleme, HB-42, Ardu 1260B, Dimtu, Misrach and Shegae while the local varieties are known as white barley, black barley and Semereta. Baleme was the most commonly used improved variety grown in the study area. Besides, HB-42 was an improved barley variety distributed for farmers involved in extension package. Farmers in the study area on average applied $187 \mathrm{~kg}$ of barley per hectare. Dashen, Qubssa, ET-13, Kenya, bonde, lakech and galama were among the improved wheat variety grown in welmera district. In addition, ET-13, HAR 710, and HAR 1685 were improved wheat varieties distributed for extension package participants. About $245 \mathrm{~kg}$ of wheat seeds used for a hectare of land. Tef is an 
indigenous grain crop to Ethiopia. It is also a peculiar grain grown to prepare the staple Ethiopian food "Injera". Two improved varieties of tef, namely, DZ-354 and CV37 were distributed for extension participants in 1995 and 1996 production calendar. Since 1997 no improved tef seed was distributed for extension participant farmers in the study area, following the complaint that DZ-354 and CV-37 were not yielding highly. Farmers in the study area on average applied $72 \mathrm{~kg}$ of tef seed for a hectare of land. To ensure high germination rate as well as reduce the rooms for anticipated weeds, farmers applied higher seeds rate than the recommended.

DAP, and Urea were the most widely used fertilizers in the study area. Application of fertilizer for crop production started in the study area during Haile-Selassie regime. The study showed that farmers apply on average $43 \mathrm{~kg}$ of Urea and $50 \mathrm{~kg}$ of DAP for tef; $69 \mathrm{~kg}$ of Urea and $69 \mathrm{~kg}$ of DAP for Barley; and $124 \mathrm{~kg}$ of Urea and $128 \mathrm{~kg}$ of DAP for wheat(Table 3.1). In the study area, 2-4D and U-46 were the most commonly used herbicide for brood leaf weeds.

Table 3.1: Physical input - output coefficient

\begin{tabular}{llrrr}
\hline & \multicolumn{1}{c}{ Items } & Barley & \multicolumn{1}{c}{ Tef } & Wheat \\
\hline Tradable & Seed ( kg/ ha) & 187.35 & 72.12 & 245.35 \\
& Fertilizer( kg/ ha) -Urea & 69.19 & 42.58 & 123.72 \\
& -DAP & 69.19 & 49.45 & 128.06 \\
Domestic factor & 0.69 & 0.62 & 1.04 \\
& Herbicides (It) & & & \\
& Labor (man-day/ha) & & & \\
& Land preparation & 26.62 & 33.14 & 40.12 \\
& Planting & 29.41 & 8.67 & 3.10 \\
Crop husbandry & 7.14 & 25.52 & 7.38 \\
Harvesting & 51.65 & 49.24 & 51.44 \\
Threshing & 22.57 & 26.48 & 21.32 \\
& Animal-power & & & \\
Land preparation & 45.00 & 68.18 & 84.27 \\
Planting & 15.88 & 4.84 & 0.40 \\
transportation & 21.49 & 2.87 & 52.09 \\
Threshing & 20.29 & 15.76 & 30.91 \\
& Working capital & $2,558.66$ & $2,321.22$ & $2,712.84$ \\
Land rent (ha) & 1.00 & 1.00 & 1.00 \\
Productivity (kg/ha) & $2,432.35$ & $1,301.82$ & $2,372.00$ \\
\hline
\end{tabular}

Source: Own computation

Domestic factors like labor, capital and land were used for grain production in welmera district. Land preparation, weeding and harvesting were the three top peak agricultural activity periods that required the use of additional or hired labor. Both family and hired labor used in grain production were unskilled. Of the three grain 
crops, tef needs repeated land cultivation, soil packing before sowing and careful harvesting because of its small seed/ grain size.

Capital is non tradable and divided into two categories, fixed and working capital. Fixed capitals are those which can be used by farmers for a period of more than a year. These include animals reared for the purpose of traction and transportation, and farm tools. Working capital refers to the money allocated for the purchase of inputs such as seeds, fertilizers, and pesticides. Total working capital was obtained by adding all costs used to purchase inputs, hire labor and oxen-power with the assumption that all labor and oxen are obtained through hiring. Working capital for barley, tef and wheat were equivalent to 2558.66, 2321.22, and 2712.84, respectively.

Land was also the other non tradable input fixed in supply. Land was the primary limiting factor in welemera district that hindered expansion of cultivated land. Land in the country in general and in the study area in particular is owned by the government. Farmers had only usufruct right since the distribution of land in 1975. Since then, the land redistribution has been made several times until 1990. However, the youth who got married and formed a new household after the last distribution have not got any land as the land can not be sold or mortgaged.

\subsubsection{Private Prices}

Private prices were the existing market price for all inputs and outputs at the farmgate. Farmers in the study area get improved varieties from Holetta Agricultural Research Center (HARC), bureau of agriculture (BOA), and other farmers. Those farmers who collaborate with HARC get improved seed without payment as a reward for allowing their land to be used for on-farm experiment. Other farmers with interest to participate in the extension package got improved seed on credit basis from BOA. There were cases when farmers got a chance to purchase offspring's of commercial seeds and local verities from other farmers. Hence, the average seed price of barley, tef and wheat were 1.7, 2.3, and 2 birr per $\mathrm{kg}$, respectively. In 2003, the market prices of Urea and DAP in the district were 1.8 and 2.4 per kg respectively (Table 3.2). The market price of herbicide was 38 birr per liter.

Domestic factor prices vary depending on the location of production area. The wage rates vary for different crops and farm activities. However, in the entire three crop production cases, wage rate for harvesting and threshing was higher than the rate for land preparation, planting and crop husbandry. Working capital is usually borrowed in June and repaid in February. The cost of working capital was 10.5 percent per annum 
of which 3 percent was sales tax. Therefore, the cost of working capital for nine months was equivalent to 7.875 percent.

Table 3.2: Private prices

\begin{tabular}{llrrr}
\hline & Items & Barley & Tef & Wheat \\
\hline Tradable & Seed ( kg/ ha) & 1.70 & 2.30 & 2.01 \\
& Fertilizer( kg/ ha) - Urea & 1.80 & 1.80 & 1.80 \\
& -DAP & 2.40 & 2.40 & 2.40 \\
& Herbicides (It) & 38.00 & 38.00 & 38.00 \\
Domestic factor & & & \\
& Labor (man-day/ha) & 7.00 & 5.00 & 6.00 \\
& Land preparation & 7.00 & 5.00 & 6.00 \\
& Planting & 7.00 & 5.00 & 6.00 \\
Crop husbandry & 8.00 & 12.00 & 7.00 \\
$\quad$ Harvesting & 8.00 & 12.00 & 7.00 \\
$\quad$ Threshing & & & \\
& Animal-power & 7.00 & 7.50 & 5.00 \\
$\quad$ Land preparation & 7.00 & 8.00 & 5.00 \\
$\quad$ Planting & 12.00 & 8.00 & 5.00 \\
Transportation & 10.00 & 7.50 & 5.00 \\
$\quad$ Threshing & 0.08 & 0.08 & 0.08 \\
& Working capital & 17.00 & 17.00 & 17.00 \\
Land rent(ha) & 1.09 & 2.00 & 1.47 \\
\hline
\end{tabular}

Source: own computation

\subsubsection{Private budget}

The private budget was obtained by multiplying the quantities in the input-output table by the prices per unit of each item in the prices table. Private profitability is the difference between the value of grain produced and the costs of all inputs used in the production so as to reach at private budget where all input-outputs are valued in the prevailing market prices.

The tradable input budget was equivalent to $635.6,384.7$ and 1061.6 for barley, tef and wheat, respectively. Total working capital was obtained by summing tradable input costs, value of labor, oxen power used, and land rental. It was then multiplied by the interest rate to obtain the opportunity cost of working capital. Cost of capital was about 201, 183 and 214 birr for barley, tef, and wheat, respectively. Total revenue obtained from production of barley, tef, and wheat were 2656, 2961, and 3486, respectively. Farmers who produced barley incurred a loss of 121 birr from the production of a hectare of land whereas farmers who produced tef and wheat 
generated a profit of 76 and 543 birr respectively from production of a hectare of land (Table 3.3).

Table3.3: Private budget

\begin{tabular}{|c|c|c|c|c|}
\hline & Items & Barley & Tef & Wheat \\
\hline \multirow[t]{4}{*}{ Tradable } & Seed ( kg/ ha) & 318.78 & 165.88 & 492.06 \\
\hline & Fertilizer( kg/ ha) -Urea & 124.54 & 76.64 & 222.70 \\
\hline & -DAP & 166.06 & 118.69 & 307.34 \\
\hline & Pesticide (It) & 26.25 & 23.48 & 39.53 \\
\hline \multirow[t]{13}{*}{ Domestic factor } & Labor (man-day/ha) & & & \\
\hline & Land preparation & 186.32 & 165.70 & 240.72 \\
\hline & Planting & 205.88 & 43.35 & 18.58 \\
\hline & Crop husbandry & 50.00 & 127.58 & 44.27 \\
\hline & Harvesting & 413.24 & 590.91 & 360.08 \\
\hline & Threshing & 180.59 & 317.75 & 149.24 \\
\hline & Animal-power & & & \\
\hline & Land preparation & 315.00 & 511.36 & 421.35 \\
\hline & Planting & 111.18 & 38.74 & 1.98 \\
\hline & Transportation & 257.88 & 22.96 & 260.45 \\
\hline & Threshing & 202.94 & 118.18 & 154.55 \\
\hline & Cost of capital & 201.49 & 182.80 & 213.64 \\
\hline & Land rent(ha) & 17.00 & 17.00 & 17.00 \\
\hline \multirow[t]{5}{*}{ Output } & Total revenue $(\mathrm{kg} / \mathrm{ha})$ & $2,656.13$ & $2,597.13$ & $3,486.84$ \\
\hline & Total cost (excl land) & $2,760.16$ & $2,504.01$ & $2,926.47$ \\
\hline & Profit (excl land) & -104.03 & 93.12 & 560.37 \\
\hline & Net profit & -121.03 & 76.12 & 543.37 \\
\hline & Total working capital & $2,558.66$ & $2,321.22$ & $2,712.84$ \\
\hline
\end{tabular}

Source: Own computation

\subsubsection{Import parity prices for inputs \& outputs}

Here, it is important to make distinction between 'tradable' and 'non-tradable' goods. Tradables comprise all goods and services produced in an economy which are actually or potentially imported or exported. Non-tradables are goods which do not cross country borders, due to the virtually non-tradable nature of the goods in question. The most notable difference between tradables and non-tradables arises from the process of price formation. The price of tradables is assumed to be determined by world market prices. The prices of non-tradables are assumed to be determined by domestic supply and demand (Thomson et al., 1998). Therefore, for this study purpose wheat was assumed as a tradable commodity whereas cereal barley and tef considered as non-tradable outputs. Import parity prices for tradables are equivalent to the world price of that commodity in domestic currency. However, 
an alternative approach to calculate import parity prices for non-tradables is to search for the price of a close substitute commodity to use as a proxy (Pearson et al., 2003). The calculation of social price for barley, tef, and wheat started from FOB prices. The FOB price of malt barley was taken from Belgium as a substitute to cereal barley. Tef is produced and sold to make gluten free bread in The Netherlands. The FOB price of wheat was taken from The Netherlands as a substitute to tef. The FOB price of wheat was taken from Italy as most of food aid in a form of wheat imported from Italy. Hence, the FOB price of barley, tef and wheat were 137.0, 166.0, and 146.3 US \$ per ton respectively. In addition, import parity for Urea and DAP fertilizer was an important input so as to calculate social prices and social budget for barley, tef, and wheat. Ethiopia imported DAP fertilizer in bulk from Jordan while Urea was imported in bulk from Baltic countries. Indeed, the FOB prices of DAP and Urea fertilizer were 185.60 , and 140.11 US $\$$ per ton respectively.

Table 3.4: Import parity prices for input \& outputs ${ }^{21}$

\begin{tabular}{llrrrrr}
\hline Steps & Items & Barley & Tef & Wheat & DAP & Urea \\
\hline 1 & FOB price (US \$/ ton) & 137.00 & 166.00 & 146.27 & 185.60 & 140.11 \\
2 & Fright and insurance (US \$/ ton) to & 86.30 & 86.30 & 50.00 & 42.40 & 70.87 \\
& Djibouti & & & & & \\
3 & CIF price (US \$/ ton) & 223.30 & 252.30 & 196.27 & 228.00 & 210.98 \\
4 & Exchange rate (Birr/ US \$) & 8.67 & 8.67 & 8.67 & 8.67 & 8.67 \\
5 & CIF price (Birr / ton) & 1936.01 & 2187.44 & 1701.70 & 1976.76 & 1829.20 \\
6 & Transportation and handling (birr/ qt) & 38.00 & 38.00 & 38.00 & 38.00 & 38.00 \\
7 & Parity price at wholesale (Birr/ qt) & 231.60 & 256.74 & 208.17 & 235.68 & 220.92 \\
8 & Distribution cost to farm (Birr/qt) & 2.00 & 2.00 & 2.00 & 2.00 & 2.00 \\
9 & Social price at farm gate (Birr/qt) & 233.60 & 258.74 & 210.00 & 237.68 & 222.92 \\
\hline
\end{tabular}

$\overline{\mathrm{FOB}}=$ free on board $\mathrm{CIF}=$ cost, insurance and freight

The information obtained from Shipping Lines Ethiopia indicated that Freight and insurance rate for a quintal of grain were 86.30 US \$ per ton from Belgium and The Netherlands to Djibouti port in 2003 while it was 50,42 , and 71 US\$ per ton from Italy, Jordan and Baltic countries respectively. The exchange rate was 8.67 Birr per US\$ in 2003. With this parameter, the CIF prices at Djibouti for barley, tef, wheat, DAP, and Urea were estimated to be 1936, 1900, 1702, 1977, and 1829 Birr per ton respectively. The addition of transportation and handling charges from Djibouti to Addis Ababa were equivalent to 38 birr per quintal. The import parity price at farm gate for barley, tef, and wheat were about 234, 259, 210 birr per quintal (Table 3.4).

\footnotetext{
${ }^{21}$ Source: Own computation based on the information obtained from WFP, Ethiopian Shipping Lines Agency, Marin- time and Transit Service Enterprise, Export Promotion Department, and Agricultural Input Marketing Department.
} 


\subsubsection{Social Prices}

The social prices of tradable inputs including seeds, fertilizers and herbicides were assumed equivalent to their import parity (Table 3.5). During the calculation of social prices of domestic factors, different assumptions were taken into consideration. Social wage rate was assumed the same as that of private wage rates. This was due to lack of monopsonies and oligopsonies, or trade union power which might bring market failure. Moreover, distorting policies such as minimum wage laws and pension and health insurance taxes were not common in the study area.

Social interest rate obtained by adjusting private interest rate for $3 \%$ sales tax. Hence, the interest rate for nine months was equivalent to 5.625 percent. In calculating social price of land, the next best alternative return from a hectare of land less its rent was assumed.

Table 3.5: Social prices

\begin{tabular}{llrrr}
\hline & Items & Barley & Tef & Wheat \\
\hline Tradable & Seed ( kg/ ha) & 2.34 & 2.59 & 2.10 \\
& Fertilizer( kg/ ha) -Urea & 2.23 & 2.23 & 2.23 \\
& -DAP & 2.38 & 2.38 & 2.38 \\
Domestic factor & 40.00 & 40.00 & 40.00 \\
& Pesticide (It) & & & \\
& Labor (man-day/ha) & 7.00 & 5.00 & 6.00 \\
& Land preparation & 7.00 & 5.00 & 6.00 \\
& Planting & 7.00 & 5.00 & 6.00 \\
$\quad$ Crop husbandry & 8.00 & 12.00 & 7.00 \\
$\quad$ Harvesting & 8.00 & 12.00 & 7.00 \\
$\quad$ Threshing & & & \\
& Animal-power & 7.00 & 7.50 & 5.00 \\
$\quad$ Land preparation & 7.00 & 8.00 & 5.00 \\
$\quad$ Planting & 12.00 & 8.00 & 5.00 \\
$\quad$ Transportation & 10.00 & 7.50 & 5.00 \\
$\quad$ Threshing & 0.06 & 0.06 & 0.06 \\
& Working capital & & & \\
Land rent(ha) & 2.34 & 2.59 & 2.10 \\
\hline
\end{tabular}

Source: Own computation

\subsubsection{Social budget}

Social budget was calculated by multiplying tradable inputs, domestic factors, and outputs in the input-output table by their social prices. The rent farmers were paying on land and used for calculation of the private budget was undervalued when it's 
compared with the opportunity cost of land. This was due to the policy that protects selling and mortgaging of land. Therefore, cultivated land in welmera does not have the value equivalent to its ability to generate other income that made social profitability of tef and wheat negative (Table 3.6). Negative social profitability arises mostly from imperfections in the land market.

Table 3.6: Social budget

\begin{tabular}{|c|c|c|c|c|}
\hline & Items & Barley & Tef & Wheat \\
\hline \multirow[t]{4}{*}{ Tradable } & Seed ( kg/ ha) & 437.66 & 186.79 & 515.24 \\
\hline & Fertilizer( kg/ ha)-Urea & 154.24 & 94.91 & 275.80 \\
\hline & -DAP & 164.45 & 117.54 & 304.37 \\
\hline & Pesticide (It) & 27.60 & 24.80 & 41.60 \\
\hline \multirow[t]{13}{*}{ Domestic factor } & Labor (man-day/ha) & & & \\
\hline & Land preparation & 186.32 & 165.70 & 240.72 \\
\hline & Planting & 205.88 & 43.35 & 18.58 \\
\hline & Crop husbandry & 50.00 & 127.58 & 44.27 \\
\hline & Harvesting & 413.24 & 590.91 & 360.08 \\
\hline & Threshing & 180.59 & 317.75 & 149.24 \\
\hline & Animal-power & & & \\
\hline & Land preparation & 315.00 & 511.36 & 421.35 \\
\hline & Planting & 111.18 & 38.74 & 1.98 \\
\hline & Transportation & 257.88 & 22.96 & 260.45 \\
\hline & Threshing & 202.94 & 118.18 & 154.55 \\
\hline & Cost of capital & 139.02 & 127.28 & 143.65 \\
\hline & Land rent(ha) & & & \\
\hline \multirow[t]{5}{*}{ Output } & Total revenue $(\mathrm{kg} / \mathrm{ha})$ & $5,681.98$ & $3,371.71$ & $4,981.20$ \\
\hline & Total cost (excl land) & $2,846.00$ & $2,487.85$ & $2,931.87$ \\
\hline & Gross Profit (excl land) & $2,835.98$ & 883.86 & $2,049.33$ \\
\hline & Social opportunity cost of land & $2,049.33$ & $2,049.33$ & $2,835.98$ \\
\hline & Net profit & 786.64 & $-1,165.47$ & -786.64 \\
\hline
\end{tabular}

Source: Own computation

\subsubsection{Policy Analysis Matrix (PAM)}

Policy Analysis Matrix (PAM) is an array of numbers which has twelve entries used to measure revenue and costs before and after the imposition of policy to determine the impact of agricultural policy. The PAM for barley, tef and wheat farming systems is based on the data from the private and social budgets. The private row in the PAM table uses values from the private budget; while the social row in the PAM was taken from the social budget. The third row of PAM, measuring divergences was found by subtracting the second row from first row (Table 3.7). 
Table 3.7: PAM of grain production in welmera

\begin{tabular}{|c|c|c|c|c|c|c|c|c|}
\hline \multirow{2}{*}{ 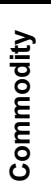 } & \multirow{2}{*}{ 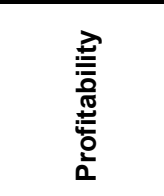 } & \multirow{2}{*}{ 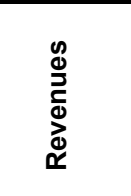 } & \multirow{2}{*}{ 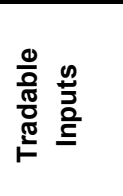 } & \multicolumn{4}{|c|}{ Domestic Factors } & \multirow{2}{*}{ profit } \\
\hline & & & & Labor & Capital & Land & Others & \\
\hline \multirow{3}{*}{ 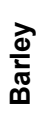 } & private & 2656.13 & 635.63 & 1036.03 & 201.49 & 17.00 & 887.00 & -121.03 \\
\hline & social & 5681.98 & 783.95 & 1036.03 & 143.92 & 2040.39 & 887.00 & 790.68 \\
\hline & divergence & -3025.85 & -148.32 & 0.00 & 57.57 & -2023.39 & 0.00 & -911.71 \\
\hline \multirow{3}{*}{ き } & private & 2597.13 & 384.69 & 1245.29 & 182.80 & 17.00 & 691.24 & 76.12 \\
\hline & social & 3254.55 & 424.05 & 1245.29 & 130.57 & 2040.39 & 691.24 & -1276.98 \\
\hline & divergence & -657.42 & -39.36 & 0.00 & 52.23 & -2023.39 & 0.00 & 1353.10 \\
\hline \multirow{3}{*}{$\begin{array}{l}\frac{ \pm}{\mathbb{\pi}} \\
\stackrel{\stackrel{5}{3}}{3}\end{array}$} & private & 3486.84 & 1061.63 & 812.88 & 213.64 & 17.00 & 838.33 & 543.37 \\
\hline & social & 4981.20 & 1137.00 & 812.88 & 152.60 & 2831.07 & 838.33 & -790.68 \\
\hline & divergence & -1494.36 & -75.38 & 0.00 & 61.04 & -2814.07 & 0.00 & 1334.05 \\
\hline
\end{tabular}

Source: Own computation

\subsection{Existing policy distortion indicators}

Comparisons of different policy scenarios are also possible through a further extension of PAM analysis. A number of ratios can be produced from PAM that indicates the effect of a policy scenario. The resulting ratios can be used to see difference between different commodity systems when there are varieties of policy scenarios. Monke and Pearson (1989) and Shapiro et al. (1995) tried to explain the advantage of using coefficients derived from PAM.

The NPCO of grain production in the farming system of welemera was less than a unit. This result implies that farmers did not receive the actual price that was equivalent with the true price. This indicates the system is not protected by policy (Table 3.8). The NPCl of barley, Tef, and wheat production in welmera was less than 1. This shows that the domestic price was lower than the comparable world prices. This has happened for two reasons. First, the system showed the presence of market failure in fertilizer market. Secondly, domestic cost of seed production was lower than the world price. In the study area, market failure of the fertilizer industry arose due to lack of perfect competition. Different fertilizer importers use many strategies to monopolize the fertilizer market. There were many small scale fertilizer distributors in welmera district because of its proximity to Addis Ababa, the center for fertilizer wholesale. To increase the market share in the central highlands, competitors reduce fertilizer price below where they can make normal profit. However, they will compensate the loss incurred by increasing price of fertilizer on remote markets of 
the country. As a result, Urea fertilizer was sold at a lower price (180 Birr) than the world price level (223Birr) in 2003 production year.

The PCR of barley, tef, and wheat farming in welmera was equal to $1.06,0.97$, and 0.78 respectively. This result indicates that tef and wheat farming systems have a competitive advantage and are privately profitable. The reverse was true for barley farming system. The DRC was less than 1 for barley and greater than 1 for tef and wheat. DRC ratio less than 1 implies that the value added calculated at private prices was less than the value added calculated at social prices. Therefore, the comparative advantage of the barley based farming system was stronger than its competitive advantage whereas tef and wheat had stronger competitive advantages than their comparative advantages.

Table 3.8; Existing policy distortion indicators of the barley, tef, and wheat production

\begin{tabular}{lllllc}
\hline \multirow{2}{*}{ No. } & \multirow{2}{*}{ Ratios } & \multirow{2}{*}{ Formula } & \multicolumn{3}{c}{ Coefficients } \\
\cline { 4 - 6 } & & & Barley & Tef & Wheat \\
\hline 1 & NPCO (Nominal protection coefficient of output) & A/E & 0.47 & 0.80 & 0.70 \\
2 & NPCI(Nominal protection coefficient of inputs ) & B/F & 0.81 & 0.91 & 0.93 \\
3 & PCR (private cost ratio) & C/(A-B) & 1.06 & 0.97 & 0.78 \\
4 & DRC (Domestic resource cost coefficient ) & G/(E-F) & 0.84 & 1.45 & 1.21 \\
5 & EPC (Effective protection coefficient ) & (A-B)/(E- & 0.41 & 0.78 & 0.63 \\
& PC (profitability coefficient ) & F) & & & \\
7 & SRP (subsidy ratio ) & D/H & -0.15 & -0.06 & -0.69 \\
7 & L/E & -0.16 & 0.42 & 0.27 \\
\hline
\end{tabular}

Source: Own computation

The EPC of barley, tef, and wheat production in welmera was lower than 1. The purpose of this coefficient was to show the joint effect of policy transfers affecting both tradable outputs and tradable inputs. In the absence of commodity price policy, the observed value added was less than the value added that would be produced at efficient prices. The PC value of the barley, tef, and wheat farming system was negative and less than 1 . The negative sign indicates that the entire grain crops didn't have both competitive and comparative advantage at the same time. Private land rental markets undervalue land relative to its ability to produce grains that made social profitability of tef and wheat negative. The SRP was 16, 31, and 26 percent for barley, tef and wheat. This means that there was divergence between private and social profits. This large transfer arises mostly from imperfections in the land market. 


\subsection{Credit repayment structure and grain price formation}

\subsubsection{Input credit}

Farmers who participated in extension package received credit in kind that were equivalent to 407,000.75 Birr in the crop calendar of 2003 (Table 3.9). This credit consisted of fertilizer (DAP and Urea), improved seeds (barley, tef and wheat), and herbicide. The credit was disbursed in July 2003 after the farmers paid a down payment of 102,993.2.

Table 3.9: Input provided on credit basis in $2001 / 2003^{22}$

\begin{tabular}{lrrrrrr}
\hline \multirow{2}{*}{ Particulars } & \multicolumn{3}{c}{$\mathbf{2 0 0 1}$} & \multicolumn{3}{c}{$\mathbf{2 0 0 3}$} \\
\cline { 2 - 7 } & Price & Quantity & Value in birr & Price & Quantity & Value in birr \\
\hline DAP & 259.55 & $5,643.00$ & $1,464,641.00$ & 240.00 & 700.00 & $168,000.00$ \\
Urea & 201.55 & $5,544.50$ & $1,117,494.00$ & 180.00 & 696.00 & $125,280.00$ \\
Wheat & 245.00 & 28.50 & $6,982.50$ & 38.25 & 696.00 & $26,622.00$ \\
Barley & 271.00 & 5.00 & $1,355.00$ & 298.50 & 20.00 & $5,970.00$ \\
Herbicide & 41.89 & $5,621.00$ & $235,463.70$ & 38.25 & 696.00 & $26,622.00$ \\
Sprayer & 360.00 & 34.00 & $12,240.00$ & 245.00 & 213.75 & $52,368.75$ \\
Tef & - & - & - & 356.33 & 6.00 & $2,138.00$ \\
Total & & $-2,838,176.20$ & & & $407,000.75$ \\
\hline
\end{tabular}

Source: Welmera district bureau of agriculture

Farmers started the repayment in November 2003 after they had started harvesting their first crop. The credit repayment period policy enforced farmers to repay the loan immediately after harvest and as a result, a large sum of the disbursed credit was repaid between January and March, 2004 (Figure 2). The loan recovery was 100 percent of which more than 95 percent was repaid between the periods November 2003 till June 2004.

\subsubsection{Seasonality of grain prices}

Grain price data of Holetta retailer grain market obtained from Holetta Agricultural Research Center for the period 1987 to 2004 . Statistical analysis of seasonality was made on these data. A 12- month moving average was applied to the monthly price data of seventeen years. Trend and cyclical component of the price were isolated to reach the seasonal index (Tschirley 1995). The analysis indicated that, for example, barley had the lowest Seasonal Price Index (SPI) in January while it had the highest SPI in June (figure 1).

\footnotetext{
${ }^{22}$ In 2002 there is no credit disbursement through extension package program
} 
Figure 1: Seasonal price index of barley

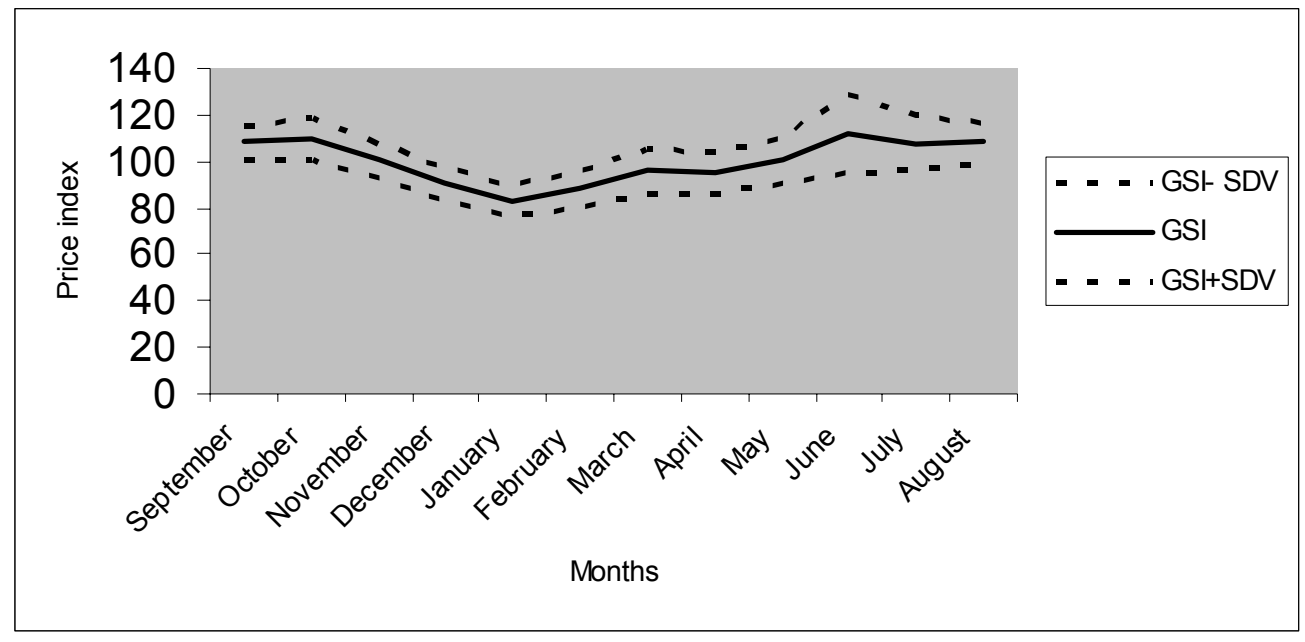

\subsubsection{Coincidence of loan repayment period with low prices}

Input credit was scheduled to be repaid immediately after harvest. During this period, prices of grain produce were at their lowest level which discouraged farmers from using improved technologies. District administration enforces farmers to repay input credit immediately after harvest with an intention to safeguard the regional budget held as collateral by banks. The $2003 / 4$ production year credit repayment structure showed January to March was a quarter of the year, during which more than 64 percent of matured credit was repaid.

The seasonal price index for barley indicated that December to February was the period during which price reached its lowest level. The seasonal price indices of tef started to decline starting from November and reached at its lowest level during March (Figure 2 \& Appendices 3). The seasonal price index of wheat reaches its lowest level in the first quarter of the year after harvest from January to March (Figure $2 \&$ Appendices 4). From this analysis it becomes clear that the selling price of grain has a difference of about 35,23 and 28 percent for barley, tef and wheat respectively. Transfers either from the producers to consumers or vice versa made possible through the use of price policy instruments (Pearson et al., 2003). However in Ethiopia, the credit repayment schedule policy seems indirectly favored consumers while it is against the producers. If credit repayment period restriction is removed, farmers can improve competitiveness of grain production by storing their produce until a period when the prices of grain improve. 
Figure 2: Seasonal price indices of barley, Tef wheat and credit repayment structure of $2003 / 4^{23}$

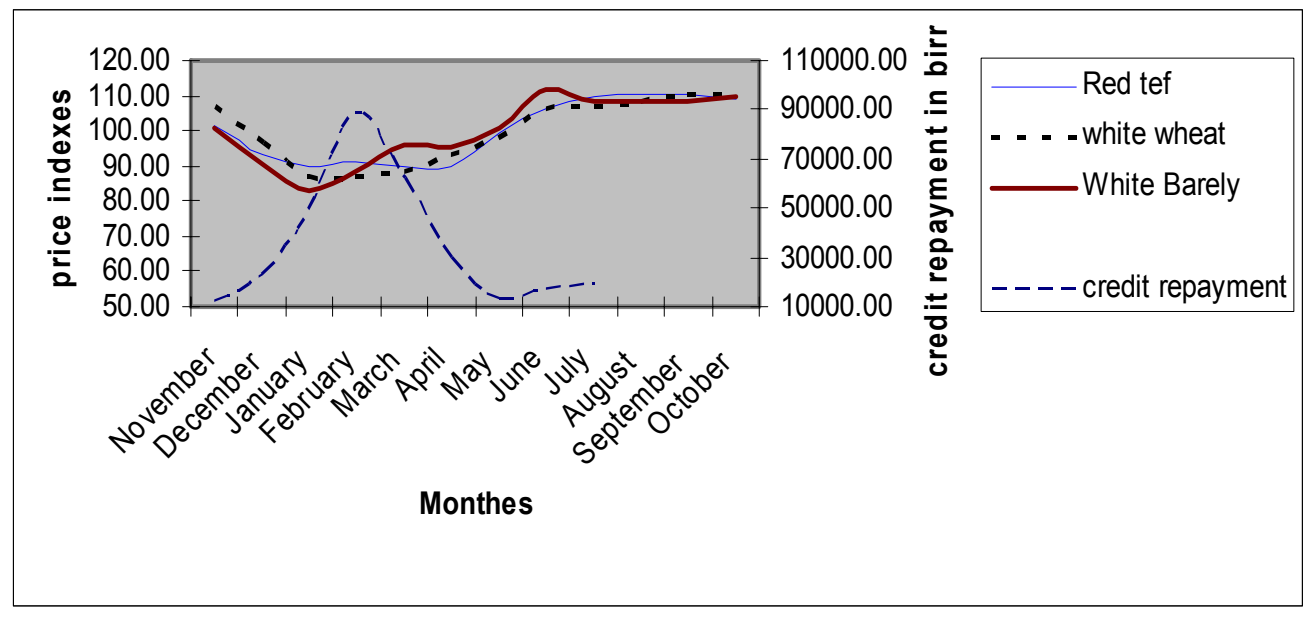

\subsection{Sensitivity analysis}

If credit repayment schedule polices are removed and farmers are able to shift selling period schedule, for all quantities of their produce, to a period when price is at peak level, or for different reasons farmers sell half of their produce with the prevailing price immediately after harvest, and keep the remaining until the price of grain reach at its peak, what would be its effect on private profitability, and competitiveness of the farming system?

\subsection{The Impact of credit repayment schedule policy}

The removal of credit repayment schedule policy enables farmers to sell their produce at price level that is 30 percent higher than price level immediately after harvest. The ratios NPCO, EPC \& SRP increase while NPCI \& DRC do not change. In contrast, the government credit repayment schedule policy forced farmers to sell significant quantity of their produce immediately after harvest. Without this policy restriction, it's assumed a rational farmer sells the entire farm produce at a period when price is at its peak. Hence, because of credit repayment schedule policy, a farmer fails to make a profit difference of 796.8, 779, and 1046 birr from barley, tef, and wheat from a hectare of land (Appendices 1). However, if farmers are able to sell half of their produce at the peak price period, they would get a profit difference which would cover the cost of tradable inputs for tef and wheat whereas the profit difference

\footnotetext{
${ }^{23}$ The price study particularly concentrates on white barley, red tef, and white wheat
} 
obtained from barley production would just be enough to cover the cost of inputs excluding seeds. The removal of credit repayment schedule policy per se would make barley production competitive even when farmers shift the sale of only one-fourth of its produce.

Table 3.10: Policy distortion indicators without credit repayment schedule policy

\begin{tabular}{ccccc}
\hline \multirow{2}{*}{ No. } & \multirow{2}{*}{ Ratios } & \multicolumn{3}{c}{ Coefficients } \\
\cline { 3 - 5 } & & Barley & Tef & Wheat \\
\hline 1 & NPCO & 0.61 & 1.00 & 0.91 \\
2 & NPCI & 0.81 & 0.91 & 0.93 \\
3 & PCR & 0.76 & 0.71 & 0.54 \\
4 & DRC & 0.84 & 1.39 & 1.21 \\
5 & EPC & 0.58 & 1.01 & 0.90 \\
6 & PC & 0.85 & -0.74 & -2.01 \\
7 & SRP & -0.02 & 0.60 & 0.48 \\
\hline
\end{tabular}

Source: Own computation

\section{Conclusion and policy recommendation}

\subsection{Summary and conclusion}

Barley in welmera district is compared with two alternative enterprises that is, tef and wheat. The DRC showed that barley production represent the most efficient use of the domestic resources of the study area followed by wheat and tef.

A farmer who maintained all quantities of his produce until a period when price is at peak level would get a profit difference of 796, 779 \&1046 birr for barley, tef and wheat respectively. For a different reason, a farmer who sells half of his produce immediately after harvest and maintains the remaining half of the produce until when price of produce is at peak, would get a profit difference of $399,390 \& 523$ birr for barley, tef $\&$ wheat respectively. Therefore, credit repayment schedule policy made farmers to receive lower profit from grain production and, eventually, making grain production in Welmera less competitive. 


\subsection{Policy recommendation}

\subsubsection{Improving barley productivity}

DRC ratio indicated that welmera district utilizes domestic resource efficiently if farmers produce barley than tef and wheat. The domestic resource cost analysis is an input for research and extension institutes, to decide allocation of scarce resources between commodities or technologies. Therefore, DRC result indicated that effort has to be made in the area of agricultural research and extension to make barley more productive than wheat and tef. The comparative advantage of welmera district for barley( especially for malt barely) coupled with improving its production and productivity will not only generate foreign currency for the country but will also help to improve the welfare of farmers involved in production of barley.

\subsubsection{Relaxing the credit repayment schedule period}

Farmers in welmera district participating in extension package program acknowledged provision of agricultural inputs on credit basis at the right time without any delay. However, the credit repayment period was scheduled to be paid during periods when price of grains were at their lowest level. Therefore, some improvements have to be made in extension package program to encourage farmers to further use agricultural technologies. Among others, the credit repayment schedule policy has to be relaxed for farmers who want to benefit from change in the seasonality of selling price.

\subsubsection{Privatizing the land}

There was a significant discrepancy between private and social value of land. This was due to the nationalization of land in 1975. Since then, land was in the hands of elder people. Youngsters only get land from their parents through in heritage. The data clearly show how government policy affected private profitability by undervaluing the value of land. However, privatization of land will have a better advantage to allocate land to the commodity that has its best alternative return.

\subsubsection{Setting price floor for producers}

The Seasonality price index analysis indicated that there was significant price variability for the selling price of grain. The prices were very low immediately after harvest and continue to increase until the harvest of the next production calendar. The government should set price floor that make producers competitive and maintain 
their income to a certain level. If the price level happens to decline below the price floor, the government should purchase grains with the help of its agents. Grain Marketing Enterprise can take this responsibility given that its mission is to maintain buffer stock of agricultural produces.

\subsection{Areas of further research}

Due to lack of sufficient information, this study could not see storage facilities and capacities of small scale farmers in the study area. The importance of this information calls the attention of researchers for further research. In addition, information such as costs of storage in the context of welmera district needs to be considered by upcoming researchers. 


\section{Reference}

Arega D. Alene and Rashid M. Hassan (2003). Measuring the impact of Ethiopia's new extension program on the productive efficiency of farmers. Proceedings of the $25^{\text {th }}$ International Conference of Agricultural Economists (IAAE). August 16 - 22, 2003 Durban, South Africa,

Belay Kassa (2003). Agricultural Extension in Ethiopia. Journal of Social Development in Africa. Vol.18 no. 1

Central Agricultural Census Commission (CACC) (2003). Results of 2000/2001 Ethiopian Agricultural Sample Enumeration (EASE).

Croppenstedt, Andre, Mulat Demeke, ane Meloria M. Meschi (2003). Technology adoption in the presence of constraints: the case of fertilizer demand in Ethiopia. Review of Development Economics, 7(1), 58-70. Blackwell publishing Itd, Oxford. UK.

Dipokusumo, Bambang, Anas Zaini, Syarif Husni, and Haeluddin (2003). Impact of agricultural policy on soybean production in west Nusa Tenggara province. Faculty of Agriculture Nusa Cendana Univeristy. Indonesia

Ellis Frank, Piyadasa Senayake, and Marisol Smith (1997). Food price policy in Sri Lanka. Food Policy, Vol.22, No.1 pp 81-96.

Flaskerud, George and Demcy Johnson (2000). NDSU Extension service, North Dakota State University

Legesse Dadi and Hailemariam Tekleweld (2004). Effect of fertilizer Market Liberalization on fertilizer distribution and farme level use. Tesfaye Zegeye, Legesse Dadi and Dawit Alemu (eds.). Agricultural technology evaluation adoption and marketing. EARO. (PP. 73-86). Proceeding of the workshop held to discuss the socio-economic research results of 1998-2002, August 68, 2002, Addis Ababa, Ethiopia

Monke, E. and S. Pearson (1989). The policy analysis matrix for agricultural development, Ithaca, NY, USA: Cornell University Press.

Pearson, Scott, Carl Gotsch and Sjaiful Bahri (2003). Applications of the Policy Analysis Matrix in Indonesian Agriculture. http://www.stanford.edu/group/FRI/Indonesia/newregional/newbook.htm

Raymakers, Benoit (2002). Review and Consequences of Reduction in Agriculture Input sales in 2002: A situation analysis. UN-Emergencies Unit for Ethiopia/OCHA

Shapiro, Barry I. and Steven J. Staal (1995). The Policy Analysis Matrix Applied to Agricultural commodity Markets. In: Scott, Gregory (ed.).1995. Price, Product, and People: Analyzing Agricultural Markets in Developing Countries. Lunne Rienner Publishers 
Thomson Anne and Manfred Metz (1998). Implications of Economic Policy for Food Security: A Training Manual. Training materials for agricultural planning 40. AO \& GTZ. Rome, Italy.

Tschirley, David L. (1995). Using Microcomputer Spreadsheets for Spatial and Temporal Price Analysis: An application to Rice and Maize in Ecuador. Gregory J. Scott, (ed) Prices, products, and people: analyzing agricultural markets in developing countries (pp. 277-300)

Wiendiyeti, Umbu Reku Raya and Poulus Un (2002). The impact of Tariff Policy and inter-island transport costs on the profitability of soya bean production in Nagada egency, NTT. Faculty of Agriculture Nusa Cendana Univeristy.

Winter-Nelson, Alex (ed.) (1991). Application of the Policy analysis matrix. Working paper. No. 91-(4). The Economic Development Institute of the World Bank. 


\section{Appendices 1 . Change in selling period schedule}

Sell all produce immediately after harvest

\begin{tabular}{|c|c|c|c|c|c|c|c|c|}
\hline \multirow{2}{*}{$\frac{5}{\frac{\pi}{\pi}}$} & \multirow[b]{2}{*}{ profitability } & \multirow[b]{2}{*}{ Revenues } & \multirow{2}{*}{$\begin{array}{l}\text { Tradable } \\
\text { inputs }\end{array}$} & \multicolumn{4}{|c|}{ Domestic Factors } & \multirow[b]{2}{*}{ profit } \\
\hline & & & & Labor & Capital & Land & others & \\
\hline \multirow{4}{*}{ 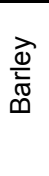 } & private & $2,656.13$ & 635.63 & $1,036.03$ & 201.49 & 17.00 & 887.00 & -121.03 \\
\hline & social & $5,681.98$ & 783.95 & $1,036.03$ & 143.92 & $2,040.39$ & 887.00 & 790.68 \\
\hline & divergence & $-3,025.85$ & -148.32 & 0.00 & 57.57 & $-2,023.39$ & 0.00 & -911.71 \\
\hline & private & $2,597.13$ & 384.69 & $1,245.29$ & 182.80 & 17.00 & 691.24 & 76.12 \\
\hline \multirow{2}{*}{ 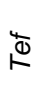 } & social & $3,254.55$ & 424.05 & $1,245.29$ & 130.57 & $2,040.39$ & 691.24 & $-1,276.98$ \\
\hline & divergence & -657.42 & -39.36 & 0.00 & 52.23 & $-2,023.39$ & 0.00 & $1,353.10$ \\
\hline \multirow{3}{*}{$\begin{array}{l}\frac{+\pi}{\Phi} \\
\stackrel{\mathscr{J}}{3}\end{array}$} & private & $3,486.84$ & $1,061.63$ & 812.88 & 213.64 & 17.00 & 838.33 & 543.37 \\
\hline & social & $4,981.20$ & $1,137.00$ & 812.88 & 152.60 & $2,831.07$ & 838.33 & -790.68 \\
\hline & divergence & $-1,494.36$ & -75.38 & 0.00 & 61.04 & $-2,814.07$ & 0.00 & $1,334.05$ \\
\hline
\end{tabular}

Shift a quarter produce to the peak price period

\begin{tabular}{|c|c|c|c|c|c|c|c|c|}
\hline \multirow{2}{*}{$\frac{5}{\frac{\pi}{N}}$} & \multirow[b]{2}{*}{ profitability } & \multirow{2}{*}{$\begin{array}{c}\text { Revenue } \\
\text { s }\end{array}$} & \multirow{2}{*}{$\begin{array}{l}\text { Tradable } \\
\text { inputs }\end{array}$} & \multicolumn{4}{|c|}{ Domestic Factors } & \multirow[b]{2}{*}{ profit } \\
\hline & & & & Labor & Capital & Land & others & \\
\hline \multirow{4}{*}{$\frac{\widehat{d}}{\frac{\pi}{\bar{D}}}$} & private & $2,855.34$ & 635.63 & $1,036.03$ & 201.49 & 17.00 & 887.00 & 78.18 \\
\hline & social & $5,681.98$ & 783.95 & $1,036.03$ & 143.92 & $2,040.39$ & 887.00 & 790.68 \\
\hline & divergence & $-2,826.64$ & -148.32 & 0.00 & 57.57 & $-2,023.39$ & 0.00 & -712.50 \\
\hline & private & $2,791.91$ & 384.69 & $1,245.29$ & 182.80 & 17.00 & 691.24 & 270.90 \\
\hline \multirow{2}{*}{$\stackrel{4}{\infty}$} & social & $3,254.55$ & 424.05 & $1,245.29$ & 130.57 & $2,040.39$ & 691.24 & $-1,276.98$ \\
\hline & divergence & -462.63 & -39.36 & 0.00 & 52.23 & $-2,023.39$ & 0.00 & $1,547.88$ \\
\hline \multirow{3}{*}{$\begin{array}{l}\frac{\pi}{\pi} \\
\stackrel{\Phi}{3}\end{array}$} & private & $3,748.35$ & $1,061.63$ & 812.88 & 213.64 & 17.00 & 838.33 & 804.88 \\
\hline & social & $4,981.20$ & $1,137.00$ & 812.88 & 152.60 & $2,831.07$ & 838.33 & -790.68 \\
\hline & divergence & $-1,232.85$ & -75.38 & 0.00 & 61.04 & $-2,814.07$ & 0.00 & $1,595.56$ \\
\hline
\end{tabular}

Shift half of a produce to the peak price period

\begin{tabular}{|c|c|c|c|c|c|c|c|c|}
\hline \multirow{2}{*}{ 高 } & \multirow[b]{2}{*}{ profitability } & \multirow[b]{2}{*}{ Revenues } & \multirow{2}{*}{$\begin{array}{l}\text { Tradable } \\
\text { inputs }\end{array}$} & \multicolumn{4}{|c|}{ Domestic Factors } & \multirow[b]{2}{*}{ profit } \\
\hline & & & & Labor & Capital & Land & others & \\
\hline \multirow{4}{*}{ 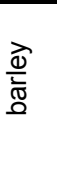 } & private & $3,054.55$ & 635.63 & $1,036.03$ & 201.49 & 17.00 & 887.00 & 277.39 \\
\hline & social & $5,681.98$ & 783.95 & $1,036.03$ & 143.92 & $2,040.39$ & 887.00 & 790.68 \\
\hline & divergence & $-2,627.43$ & -148.32 & 0.00 & 57.57 & $-2,023.39$ & 0.00 & -513.29 \\
\hline & private & $2,986.70$ & 384.69 & $1,245.29$ & 182.80 & 17.00 & 691.24 & 465.68 \\
\hline \multirow{2}{*}{ 市 } & social & $3,254.55$ & 424.05 & $1,245.29$ & 130.57 & $2,040.39$ & 691.24 & $-1,276.98$ \\
\hline & divergence & -267.85 & -39.36 & 0.00 & 52.23 & $-2,023.39$ & 0.00 & $1,742.67$ \\
\hline \multirow{3}{*}{$\begin{array}{l}\frac{\pi}{\mathbb{\infty}} \\
\stackrel{\stackrel{5}{3}}{3}\end{array}$} & private & $4,009.87$ & $1,061.63$ & 812.88 & 213.64 & 17.00 & 838.33 & $1,066.39$ \\
\hline & social & $4,981.20$ & $1,137.00$ & 812.88 & 152.60 & $2,831.07$ & 838.33 & -790.68 \\
\hline & divergence & -971.33 & -75.38 & 0.00 & 61.04 & $-2,814.07$ & 0.00 & $1,857.07$ \\
\hline
\end{tabular}


Shift three quarter of produce to the peak price period

\begin{tabular}{|c|c|c|c|c|c|c|c|c|}
\hline \multirow[b]{2}{*}{ 部 } & \multirow[b]{2}{*}{ profitability } & \multirow[b]{2}{*}{ Revenues } & \multirow[b]{2}{*}{$\begin{array}{l}\text { Tradable } \\
\text { inputs }\end{array}$} & \multicolumn{4}{|c|}{ Domestic Factors } & \multirow[b]{2}{*}{ profit } \\
\hline & & & & Labor & Capital & Land & others & \\
\hline \multirow{4}{*}{$\begin{array}{l}\frac{\widehat{\varpi}}{\frac{\pi}{\pi}} \\
\infty\end{array}$} & private & $3,253.76$ & 635.63 & $1,036.03$ & 201.49 & 17.00 & 887.00 & 476.60 \\
\hline & social & $5,681.98$ & 783.95 & $1,036.03$ & 143.92 & $2,040.39$ & 887.00 & 790.68 \\
\hline & divergence & $-2,428.22$ & -148.32 & 0.00 & 57.57 & $-2,023.39$ & 0.00 & -314.08 \\
\hline & private & $3,181.48$ & 384.69 & $1,245.29$ & 182.80 & 17.00 & 691.24 & 660.47 \\
\hline \multirow{2}{*}{$\stackrel{4}{\stackrel{2}{r}}$} & social & $3,254.55$ & 424.05 & $1,245.29$ & 130.57 & $2,040.39$ & 691.24 & $-1,276.98$ \\
\hline & divergence & -73.06 & -39.36 & 0.00 & 52.23 & $-2,023.39$ & 0.00 & $1,937.45$ \\
\hline \multirow{3}{*}{ 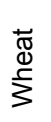 } & private & $4,271.38$ & $1,061.63$ & 812.88 & 213.64 & 17.00 & 838.33 & $1,327.91$ \\
\hline & social & $4,981.20$ & $1,137.00$ & 812.88 & 152.60 & $2,831.07$ & 838.33 & -790.68 \\
\hline & divergence & -709.82 & -75.38 & 0.00 & 61.04 & $-2,814.07$ & 0.00 & $2,118.59$ \\
\hline
\end{tabular}

Shift all produce to the peak price period

\begin{tabular}{|c|c|c|c|c|c|c|c|c|}
\hline \multirow{2}{*}{$\frac{5}{\frac{\pi}{\pi}}$} & \multirow{2}{*}{ profitability } & \multirow{2}{*}{ Revenues } & \multirow{2}{*}{$\begin{array}{l}\text { Tradable } \\
\text { inputs }\end{array}$} & \multicolumn{4}{|c|}{ Domestic Factors } & \multirow{2}{*}{ profit } \\
\hline & & & & Labor & Capital & Land & others & \\
\hline \multirow{4}{*}{$\frac{\widehat{\varpi}}{\frac{\pi}{\pi}}$} & private & $3,452.97$ & 635.63 & $1,036.03$ & 201.49 & 17.00 & 887.00 & 675.81 \\
\hline & social & $5,681.98$ & 783.95 & $1,036.03$ & 143.92 & $2,040.39$ & 887.00 & 790.68 \\
\hline & divergence & $-2,229.01$ & -148.32 & 0.00 & 57.57 & $-2,023.39$ & 0.00 & -114.87 \\
\hline & private & $3,376.27$ & 384.69 & $1,245.29$ & 182.80 & 17.00 & 691.24 & 855.25 \\
\hline \multirow{2}{*}{ 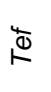 } & social & $3,254.55$ & 424.05 & $1,245.29$ & 130.57 & $2,040.39$ & 691.24 & $-1,276.98$ \\
\hline & divergence & 121.72 & -39.36 & 0.00 & 52.23 & $-2,023.39$ & 0.00 & $2,132.24$ \\
\hline \multirow{3}{*}{ 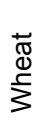 } & private & $4,532.89$ & $1,061.63$ & 812.88 & 213.64 & 17.00 & 838.33 & $1,589.42$ \\
\hline & social & $4,981.20$ & $1,137.00$ & 812.88 & 152.60 & $2,831.07$ & 838.33 & -790.68 \\
\hline & divergence & -448.31 & -75.38 & 0.00 & 61.04 & $-2,814.07$ & 0.00 & $2,380.10$ \\
\hline
\end{tabular}


Ethiopian Journal of Economics, Volume XIV, No 1, April 2005

\begin{tabular}{|c|c|c|c|c|c|c|c|c|c|c|c|c|}
\hline Year & January & Feb. & March & April & May & June & July & August & Sept. & Oct. & Nov. & Dec. \\
\hline 1988 & 80.44 & 82.33 & 90.53 & 80.83 & 99.63 & 108.70 & 113.52 & 121.97 & 120.40 & 113.93 & 98.19 & 81.55 \\
\hline 1989 & 77.41 & 84.67 & 95.70 & 105.87 & 106.72 & 103.00 & 108.22 & 97.12 & 105.85 & 99.86 & 101.99 & 98.45 \\
\hline 1990 & 91.06 & 96.25 & 97.34 & 89.14 & 88.82 & 164.50 & 84.45 & 98.82 & 97.64 & 102.16 & 89.11 & 79.15 \\
\hline 1991 & 68.89 & 69.22 & 85.94 & 100.70 & 114.22 & 127.35 & 117.79 & 116.04 & 116.66 & 111.66 & 103.54 & 86.60 \\
\hline 1992 & 73.94 & 79.71 & 106.94 & 116.63 & 118.18 & 91.13 & 96.95 & 109.52 & 110.79 & 114.02 & 100.37 & 81.28 \\
\hline 1993 & 79.51 & 89.84 & 99.42 & 101.62 & 102.98 & 106.61 & 95.86 & 98.01 & 109.44 & 103.05 & 97.02 & 85.78 \\
\hline 1994 & 80.16 & 88.72 & 87.25 & 89.88 & 114.68 & 120.35 & 124.41 & 120.01 & 116.55 & 99.28 & 83.09 & 87.53 \\
\hline 1995 & 83.68 & 102.00 & 93.85 & 94.29 & 101.15 & 109.98 & 118.65 & 108.85 & 112.59 & 99.69 & 88.87 & 94.26 \\
\hline 1996 & 96.81 & 98.76 & 92.99 & 89.12 & 89.83 & 111.25 & 107.33 & 101.95 & 94.83 & 110.37 & 104.07 & 99.24 \\
\hline 1997 & 83.06 & 77.91 & 80.68 & 92.14 & 87.63 & 127.42 & 130.49 & 111.49 & 110.40 & 116.58 & 106.92 & 93.52 \\
\hline 1998 & 82.99 & 81.23 & 85.93 & 88.79 & 92.45 & 104.46 & 105.46 & 108.48 & 110.49 & 112.46 & 99.01 & 94.02 \\
\hline 1999 & 81.67 & 87.49 & 96.42 & 88.69 & 105.08 & 111.06 & 110.16 & 112.98 & 102.29 & 126.37 & 103.43 & 88.25 \\
\hline 2000 & 79.20 & 89.97 & 98.02 & 103.11 & 103.44 & 111.09 & 110.44 & 111.08 & 107.89 & 119.01 & 100.03 & 79.43 \\
\hline 2001 & 85.25 & 95.60 & 103.38 & 88.32 & 97.88 & 93.14 & 96.56 & 90.87 & 95.59 & 89.78 & 104.12 & 99.47 \\
\hline 2002 & 84.48 & 91.24 & 122.29 & 92.64 & 84.98 & 94.55 & 104.78 & 107.58 & 103.21 & 113.15 & 110.68 & 97.92 \\
\hline 2003 & 90.38 & 91.29 & 96.91 & 98.89 & 94.57 & 105.18 & 101.33 & 114.15 & 108.10 & 109.83 & 108.46 & 96.70 \\
\hline 2004 & 86.07 & 91.65 & 92.53 & 93.65 & 99.02 & 106.33 & 103.07 & 103.30 & 108.71 & 113.38 & 104.69 & 89.81 \\
\hline$N$ & 17.00 & 17.00 & 17.00 & 17.00 & 17.00 & 17.00 & 17.00 & 17.00 & 17.00 & 17.00 & 17.00 & 17.00 \\
\hline Max & 96.81 & 102.00 & 122.29 & 116.63 & 118.18 & 164.50 & 130.49 & 121.97 & 120.40 & 126.37 & 110.68 & 99.47 \\
\hline Min & 68.89 & 69.22 & 80.68 & 80.83 & 84.98 & 91.13 & 84.45 & 90.87 & 94.83 & 89.78 & 83.09 & 79.15 \\
\hline Mean & 82.65 & 88.11 & 95.65 & 94.96 & 100.07 & 111.54 & 107.62 & 107.78 & 107.73 & 109.09 & 100.21 & 90.17 \\
\hline GSI & 82.95 & 88.44 & 96.01 & 95.31 & 100.44 & 111.95 & 108.01 & 108.18 & 108.13 & 109.50 & 100.58 & 90.51 \\
\hline Std Error & 1.58 & 2.00 & 2.31 & 2.08 & 2.38 & 4.14 & 2.75 & 2.05 & 1.76 & 2.17 & 1.78 & 1.73 \\
\hline Std Dev & 6.52 & 8.26 & 9.53 & 8.58 & 9.81 & 17.05 & 11.36 & 8.46 & 7.24 & 8.95 & 7.32 & 7.14 \\
\hline $\mathrm{t}$-value & -10.78 & -5.77 & -1.73 & -2.25 & 0.19 & 2.89 & 2.91 & 3.98 & 4.63 & 4.37 & 0.33 & -5.48 \\
\hline GSI-STD & 76.43 & 80.18 & 86.48 & 86.73 & 90.63 & 94.89 & 96.66 & 99.72 & 100.89 & 100.54 & 93.26 & 83.36 \\
\hline GSI & 82.95 & 88.44 & 96.01 & 95.31 & 100.44 & 111.95 & 108.01 & 108.18 & 108.13 & 109.50 & 100.58 & 90.51 \\
\hline GSI+ STD & 89.48 & 96.70 & 105.53 & 103.89 & 110.26 & 129.00 & 119.37 & 116.64 & 115.37 & 118.45 & 107.91 & 97.65 \\
\hline
\end{tabular}

Source: Own computation 


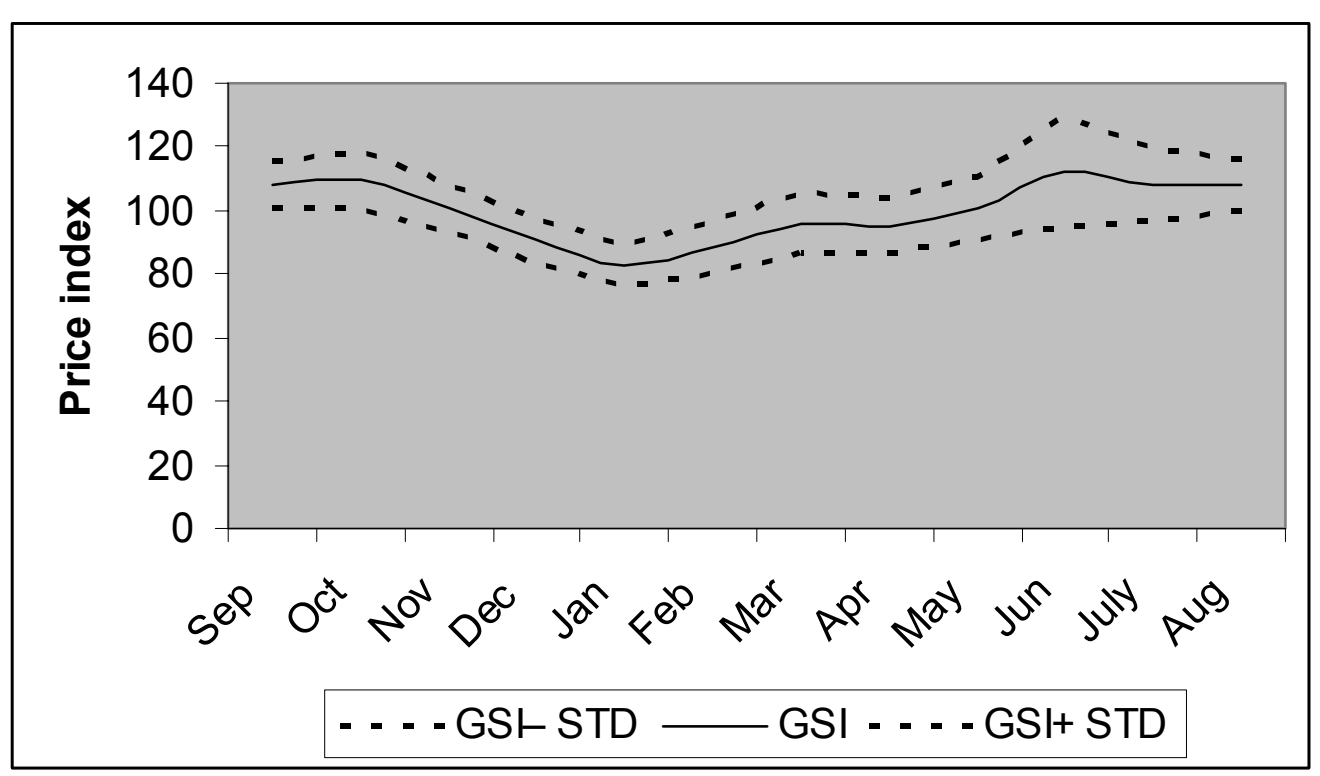


Ethiopian Journal of Economics, Volume XIV, No 1, April 2005

\begin{tabular}{|c|c|c|c|c|c|c|c|c|c|c|c|c|}
\hline Year & Jan & Feb & Mar & April & May & June & July & Aug & Sep & Oct & Nov & Dec \\
\hline 1988 & 96.07 & 100.28 & 90.77 & 81.65 & 89.73 & 97.85 & 109.76 & 127.32 & 121.24 & 121.75 & 98.46 & 85.44 \\
\hline 1989 & 86.44 & 87.22 & 93.93 & 101.27 & 93.10 & 94.72 & 104.72 & 100.22 & 99.57 & 101.71 & 108.41 & 107.20 \\
\hline 1990 & 109.09 & 113.73 & 84.93 & 78.69 & 82.49 & 102.99 & 104.53 & 109.81 & 107.29 & 108.07 & 96.08 & 84.87 \\
\hline 1991 & 82.56 & 81.64 & 91.66 & 101.36 & 110.59 & 119.72 & 117.15 & 113.46 & 105.36 & 104.85 & 100.27 & 87.08 \\
\hline 1992 & 87.24 & 90.77 & 93.63 & 100.84 & 95.83 & 102.62 & 105.65 & 109.48 & 112.28 & 114.84 & 113.51 & 97.13 \\
\hline 1993 & 94.00 & 92.09 & 90.13 & 86.39 & 96.79 & 100.78 & 101.24 & 104.36 & 104.78 & 106.02 & 100.06 & 87.41 \\
\hline 1994 & 80.64 & 82.08 & 82.69 & 86.83 & 109.21 & 118.10 & 121.04 & 121.30 & 119.34 & 96.29 & 97.65 & 87.33 \\
\hline 1995 & 87.15 & 92.42 & 94.15 & 100.40 & 104.04 & 107.91 & 111.01 & 113.53 & 105.86 & 105.68 & 105.06 & 98.37 \\
\hline 1996 & 96.85 & 91.44 & 88.95 & 87.14 & 86.19 & 99.86 & 112.15 & 104.32 & 106.86 & 109.37 & 100.68 & 93.63 \\
\hline 1997 & 85.61 & 85.17 & 82.52 & 82.89 & 80.12 & 116.07 & 115.87 & 113.32 & 116.95 & 112.71 & 110.85 & 100.56 \\
\hline 1998 & 85.77 & 90.28 & 86.68 & 84.00 & 88.94 & 108.44 & 108.07 & 114.69 & 118.07 & 116.22 & 103.30 & 81.01 \\
\hline 1999 & 77.30 & 84.51 & 89.91 & 86.44 & 103.66 & 119.78 & 118.89 & 117.10 & 118.12 & 112.56 & 91.69 & 81.28 \\
\hline 2000 & 81.96 & 92.11 & 95.96 & 99.27 & 105.81 & 112.74 & 112.58 & 108.79 & 110.50 & 114.50 & 94.02 & 93.25 \\
\hline 2001 & 94.22 & 98.90 & 97.28 & 88.74 & 91.26 & 88.44 & 90.42 & 95.07 & 101.75 & 105.97 & 99.79 & 97.63 \\
\hline 2002 & 87.35 & 78.19 & 78.27 & 80.72 & 154.56 & 101.12 & 105.14 & 99.51 & 98.09 & 95.45 & 93.28 & 106.79 \\
\hline 2003 & 112.49 & 97.38 & 88.67 & 90.49 & 93.70 & 106.55 & 113.26 & 115.25 & 116.51 & 110.82 & 98.14 & 91.06 \\
\hline 2004 & 81.67 & 85.10 & 95.02 & 91.89 & 97.37 & 107.60 & 110.13 & 105.08 & 105.09 & 109.02 & 105.46 & 98.40 \\
\hline $\mathrm{n}$ & 17.00 & 17.00 & 17.00 & 17.00 & 17.00 & 17.00 & 17.00 & 17.00 & 17.00 & 17.00 & 17.00 & 17.00 \\
\hline $\max$ & 112.49 & 113.73 & 97.28 & 101.36 & 154.56 & 119.78 & 121.04 & 127.32 & 121.24 & 121.75 & 113.51 & 107.20 \\
\hline $\min$ & 77.30 & 78.19 & 78.27 & 78.69 & 80.12 & 88.44 & 90.42 & 95.07 & 98.09 & 95.45 & 91.69 & 81.01 \\
\hline Mean & 89.79 & 90.78 & 89.71 & 89.94 & 99.02 & 106.19 & 109.51 & 110.15 & 109.86 & 108.58 & 100.98 & 92.85 \\
\hline GSI & 89.99 & 90.98 & 89.91 & 90.14 & 99.24 & 106.43 & 109.75 & 110.40 & 110.10 & 108.82 & 101.20 & 93.05 \\
\hline Std. Error & 2.35 & 2.07 & 1.28 & 1.91 & 4.09 & 2.18 & 1.79 & 1.99 & 1.78 & 1.66 & 1.48 & 1.97 \\
\hline Std. Deviation & 9.68 & 8.54 & 5.29 & 7.85 & 16.84 & 9.00 & 7.37 & 8.22 & 7.36 & 6.85 & 6.11 & 8.11 \\
\hline t-value & -4.27 & -4.35 & -7.86 & -5.18 & -0.19 & 2.95 & 5.45 & 5.21 & 5.66 & 5.30 & 0.81 & -3.53 \\
\hline GSI-SDV & 80.31 & 82.44 & 84.62 & 82.29 & 82.40 & 97.43 & 102.37 & 102.18 & 102.74 & 101.96 & 95.09 & 84.94 \\
\hline GSI & 89.99 & 90.98 & 89.91 & 90.14 & 99.24 & 106.43 & 109.75 & 110.40 & 110.10 & 108.82 & 101.20 & 93.05 \\
\hline GSI+SDV & 99.66 & 99.52 & 95.20 & 97.99 & 116.08 & 115.42 & 117.12 & 118.62 & 117.46 & 115.67 & 107.32 & 101.16 \\
\hline
\end{tabular}

Source: Own computation 


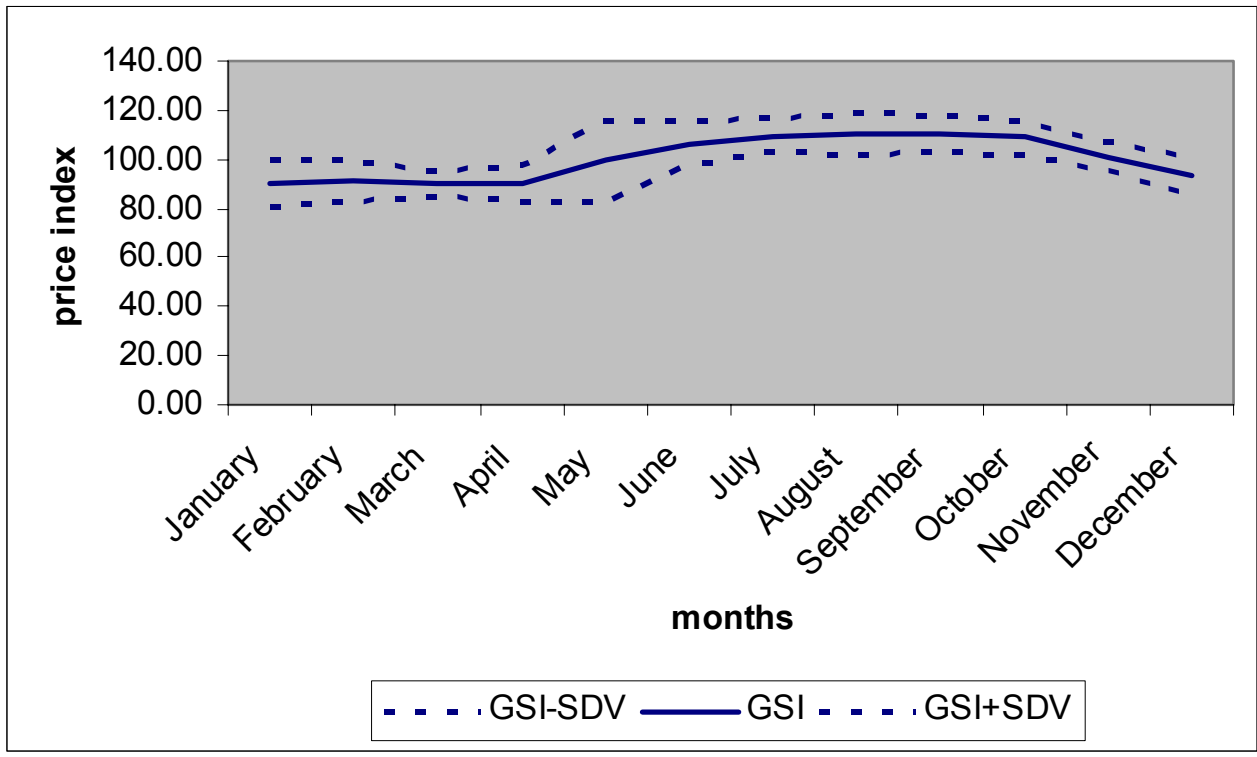


Ethiopian Journal of Economics, Volume XIV, No 1, April 2005

\begin{tabular}{|c|c|c|c|c|c|c|c|c|c|c|c|c|}
\hline Year & January & February & March & April & May & June & July & August & Sept. & Oct. & Nov. & Dec. \\
\hline 1988 & 87.47 & 75.52 & 82.49 & 79.51 & 96.62 & 108.56 & 107.64 & 110.09 & 117.33 & 118.66 & 106.80 & 99.60 \\
\hline 1989 & 83.58 & 82.89 & 87.53 & 98.11 & 101.89 & 107.44 & 103.25 & 102.18 & 106.65 & 105.27 & 98.08 & 107.00 \\
\hline 1990 & 102.89 & 96.98 & 87.18 & 92.51 & 90.14 & 115.55 & 90.45 & 92.66 & 99.24 & 106.41 & 98.68 & 95.88 \\
\hline 1991 & 83.23 & 77.98 & 88.12 & 97.39 & 106.21 & 114.97 & 113.01 & 111.37 & 117.91 & 114.47 & 111.94 & 101.22 \\
\hline 1992 & 82.21 & 87.68 & 86.31 & 91.62 & 93.02 & 105.01 & 101.13 & 114.08 & 115.32 & 116.46 & 117.35 & 92.58 \\
\hline 1993 & 84.12 & 83.16 & 83.36 & 91.74 & 98.03 & 102.17 & 106.63 & 105.89 & 107.63 & 107.87 & 102.97 & 89.91 \\
\hline 1994 & 82.60 & 83.90 & 87.79 & 93.30 & 107.41 & 111.78 & 113.64 & 115.65 & 120.33 & 109.48 & 99.59 & 84.36 \\
\hline 1995 & 80.80 & 89.78 & 96.08 & 106.60 & 104.07 & 101.35 & 112.99 & 106.06 & 108.03 & 110.83 & 106.00 & 91.87 \\
\hline 1996 & 92.88 & 88.39 & 90.45 & 91.50 & 89.17 & 97.85 & 109.83 & 107.11 & 105.80 & 111.81 & 101.04 & 97.32 \\
\hline 1997 & 84.34 & 79.25 & 79.48 & 90.79 & 93.70 & 108.56 & 108.65 & 112.77 & 116.71 & 113.14 & 121.46 & 92.15 \\
\hline 1998 & 87.00 & 92.21 & 91.76 & 92.35 & 97.16 & 102.43 & 103.61 & 104.55 & 106.44 & 107.07 & 104.29 & 86.34 \\
\hline 1999 & 85.79 & 85.87 & 90.40 & 91.60 & 101.81 & 109.67 & 116.53 & 116.19 & 115.89 & 118.67 & 102.11 & 90.49 \\
\hline 2000 & 80.71 & 84.40 & 86.45 & 93.90 & 104.98 & 113.55 & 114.50 & 111.85 & 113.43 & 114.81 & 109.67 & 90.19 \\
\hline 2001 & 88.77 & 93.79 & 92.76 & 88.05 & 91.53 & 93.12 & 93.89 & 98.11 & 98.92 & 99.60 & 99.36 & 102.87 \\
\hline 2002 & 95.62 & 87.49 & 81.26 & 86.75 & 90.35 & 98.77 & 103.12 & 105.17 & 105.58 & 108.12 & 104.77 & 103.46 \\
\hline 2003 & 100.08 & 95.73 & 94.51 & 96.36 & 98.66 & 104.27 & 107.85 & 112.31 & 112.73 & 103.26 & 117.54 & 110.41 \\
\hline 2004 & 70.39 & 83.59 & 90.12 & 94.42 & 97.98 & 102.68 & 103.27 & 108.34 & 104.54 & 107.10 & 104.27 & 95.82 \\
\hline$n$ & 17.00 & 17.00 & 17.00 & 17.00 & 17.00 & 17.00 & 17.00 & 17.00 & 17.00 & 17.00 & 17.00 & 17.00 \\
\hline $\max$ & 102.89 & 96.98 & 96.08 & 106.60 & 107.41 & 115.55 & 116.53 & 116.19 & 120.33 & 118.67 & 121.46 & 110.41 \\
\hline $\min$ & 70.39 & 75.52 & 79.48 & 79.51 & 89.17 & 93.12 & 90.45 & 92.66 & 98.92 & 99.60 & 98.08 & 84.36 \\
\hline Mean & 86.62 & 86.39 & 88.00 & 92.74 & 97.81 & 105.75 & 106.47 & 107.91 & 110.15 & 110.18 & 106.23 & 95.97 \\
\hline GSI & 87.04 & 86.81 & 88.43 & 93.19 & 98.28 & 106.26 & 106.99 & 108.43 & 110.68 & 110.71 & 106.75 & 96.43 \\
\hline Std. Error & 1.89 & 1.47 & 1.11 & 1.36 & 1.43 & 1.53 & 1.72 & 1.52 & 1.59 & 1.30 & 1.72 & 1.76 \\
\hline Std. Deviation & 7.79 & 6.06 & 4.59 & 5.60 & 5.90 & 6.32 & 7.09 & 6.28 & 6.56 & 5.38 & 7.10 & 7.28 \\
\hline t-value & -6.86 & -8.98 & -10.40 & -5.02 & -1.20 & 4.09 & 4.06 & 5.54 & 6.71 & 8.22 & 3.92 & -2.02 \\
\hline GSI-SDV & 79.24 & 80.75 & 83.84 & 87.58 & 92.38 & 99.95 & 99.90 & 102.15 & 104.12 & 105.34 & 99.64 & 89.16 \\
\hline GSI & 87.04 & 86.81 & 88.43 & 93.19 & 98.28 & 106.26 & 106.99 & 108.43 & 110.68 & 110.71 & 106.75 & 96.43 \\
\hline GSI+SDV & 94.83 & 92.87 & 93.02 & 98.79 & 104.18 & 112.58 & 114.08 & 114.71 & 117.24 & 116.09 & 113.85 & 103.71 \\
\hline
\end{tabular}

Source: Own computation 


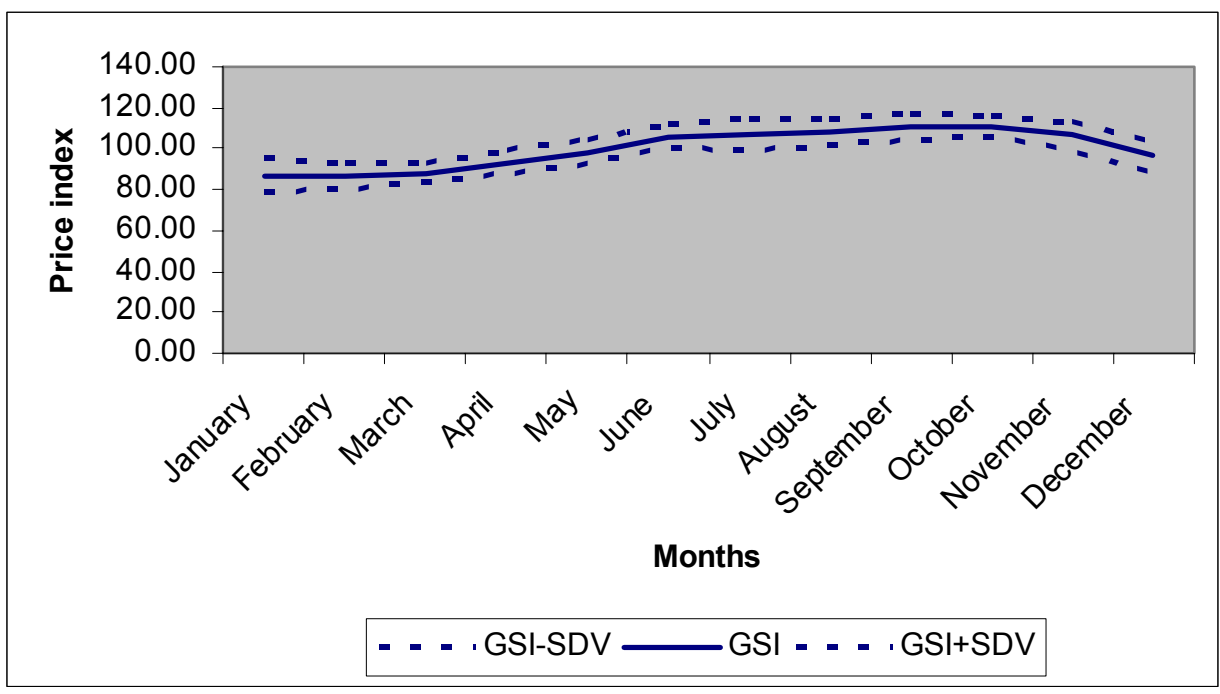

